\title{
Hydrologic Characteristics of Vegetation Types as Affected by Livestock Grazing Systems, Edwards Plateau, Texas
}

\author{
T.L. THUROW, W.H. BLACKBURN, C.A. TAYLOR, JR.
}

\section{Abstract}

Infiltration rate and sediment production were assessed in oak, bunchgrass and sodgrass vegetation types in moderate continuous (MCG), heavy continuous (HCG), and intensive rotation (shortduration, SDG) grazing systems and in a livestock exclosure (LEX). Infiltration rate was related to the total organic cover and bulk density characteristics of the site $\left(R^{2}=.86\right)$. The amount of cover was more important than type, indicating that protection of soil structure from direct raindrop impact was the primary function of cover on infiltration. The SDG and HCG pastures had lower total organic cover with correspondingly lower infiltration rates compared to the MCG and LEX pastures. Bulk density, an indicator of soil structure, was significantly lower in oak mottes than in the grass interspace, but there was no significant difference between pastures. Sediment production was related to the total aboveground biomass and the bunchgrass cover of the site $\left(R^{2}=\right.$ .79). Obstruction to overland sediment transport and protection from the disaggregating effect of direct raindrop impact were the primary functions of the total aboveground biomass and bunchgrass cover. Total aboveground biomass was greatest in the oak motte and least in the sodgrass interspace, consequently the sodgrass interspace had the greatest amount of sediment production and the oak mottes had the least sediment production. Midgrass cover and total aboveground biomass in the MCG and LEX pastures was significantly greater than in the SDG and HCG pastures; thus sediment production from the MCG and LEX pastures was significantly lower than from the SDG and HCG pastures.

The hydrologic condition of a range site is the result of complex interactions of soil and vegetation factors. Infiltration rate and sediment production integrate these factors and are good indicators of hydrologic condition. The type of livestock grazing system and stocking rate differentially impact soil structure and vegetation growth in different plant communities. Successional trends in plant communities were directly proportional to grazing intensity, with the most severe changes occurring under heavy grazing (Ellison 1960). Palatable species decline as grazing pressure increases and are replaced by shrubs or other vegetation which are less preferred by livestock and more resistant to grazing (Dyksterhuis 1949). Perennial bunchgrasses are especially important indicators of rangeland condition in the Edwards Plateau of Texas. Many bunchgrass species are palatable and nutritious for livestock and provide good soil stabilization. However, many bunchgrasses have aboveground apical meristems and are not tolerant of repeated heavy grazing. Rich and Reynolds (1963) found that perennial bunchgrass basal cover was reduced by heavy grazing but was unaffected by moderate grazing. Rhoades et al. (1964), Sharp et al. (1964) and Dunford and Weitzman (1955) found that heavily grazed pastures were dominated by sod-forming grasses whereas bunchgrasses dominated moderate and non-grazed pastures.

\footnotetext{
The authors are presently range research scientist, P.O. Box 2954, Mogadishu, Somalia; professor of watershed management, Department of Range Science, Texas A\&M University, College Station 77843; and superintendent of the Texas Agricultural Experiment Station at Sonora 76950 . Send reprint requests to second author. At the time of research, the senior author was graduate research assistant, Department of Range Science, Texas A\&M University.

The authors would like to thank the personnel of the Texas Agricultural Research Station at Sonora and Ronnie Anson for their help during this study. This study was a cooperative project between U.S. Department of Agriculture and Texas Agricultura Experiment Station. Financial support of the Soil Conservation Service RCA Special Study and a Science/Education Grant is acknowledged.

Published with the approval of the Director, Texas Agricultural Experiment Station as TA - 20746.

Manuscript accepted 29 May 1986.
}

Infiltration rates are generally observed to be highest under trees and shrubs, followed in decreasing order by bunchgrasses and sodgrasses (Smith and Leopold 1941, Woodward 1943, Reed and Peterson 1961, Box 1961, Blackburn 1975, Wood and Blackburn 1981, Knight et al. 1984). Each life form responds differently to grazing pressure and range improvement practices. The extent to which these rangeland uses alter the vegetation composition is a prime factor determining the effects on the soil structure and hydrologic condition of the site.

The objective of this research was to study oak, bunchgrass, and sodgrass plant communities to determine how their infiltration rate and sediment production differ from each other. Also, the infiltration rate and sediment production of each of the 3 plant communities was studied to determine how the effects of livestock grazing systems differ for each plant community under moderate continuous, heavy continuous, and intensive rotation grazing systems and livestock.

\section{Study Area}

The study was conducted during May, 1984, at the Texas Agricultural Experiment Station located about $56 \mathrm{~km}$ south of Sonora, in Sutton and Edwards Counties, Texas $\left(31^{\circ} \mathrm{N} ; 100^{\circ} \mathrm{W}\right)$. The rolling stony hill topography that characterizes the station is typical of the Edwards Plateau. The average growing season on the station is $\mathbf{2 4 0}$ days. Precipitation is highly variable within a year and in annual amount (range, 1918-1984, varies from $156 \mathrm{~mm}$ to $1,054 \mathrm{~mm}$; median of $438 \mathrm{~mm}$ ). Most precipitation results from intense, short duration thunderstorms.

The vegetation types of the study site can be characterized as being dominated by either oak mottes, bunchgrass, or sodgrass. Oak mottes dominated $27 \%$ of the land area of the study site and were composed primarily of live oak (Quercus virginiana Mill.). Bunchgrasses dominated $30 \%$ of the study site with the primary species being sideoats grama (Bouteloua curtipendula (Michx.) Torr.), Texas wintergrass (Stipa leucotricha Trin. and Rupr.), and threeawn (Aristida spp.). Sodgrasses, primarily curlymesquite (Hilaria belangeri (Steud.) Nash), dominated $43 \%$ of the study site.

\section{Methods}

The infiltration rate and sediment production of oak motte, bunchgrass, and sodgrass vegetation types were determined in 4 different treatment pastures. The study pastures were adjacent to each other and were selected for this study because they had similar soils (Tarrent silty clays averaging $273 \mathrm{~mm}$ depth and overlying an undulating fractured caliche), similar slope (1-2\%), and the same past grazing history (grazed at a moderate continuous rate of 8.1 ha/au/yr from 1949-1978). Three grazing regimes were established in 1978: moderate continuous grazing (MCG) stocked at 8.1 ha/ au/yr; heavy continuous grazing (HCG) stocked at $4.6 \mathrm{ha} / \mathrm{au} / \mathrm{yr}$; and a high-intensity low frequency (HILF) system (8-1; 17:119 day) stocked at $8.1 \mathrm{ha} / \mathrm{au} / \mathrm{yr}$. In January, 1980, the HILF pasture was changed to an intensive rotation (short duration grazing, SDG) system (14-1; 4:50 day) and stocked at $4.6 \mathrm{ha} / \mathrm{au} / \mathrm{yr}$, and a livestock exclosure (LEX) was established. The stocking ratio for the grazed pastures was 50:25:25 cattle, sheep, and goats.

The study site not only had similar grazing history, soil, and vegetation prior to study initiation in 1978, but were similar hydrologically. Infiltration rate and sediment production of the site prior 
to this study was similar within vegetation type. Pretreatment infiltration rates averaged $22 \mathrm{~cm} \mathrm{~h}^{-1}$ for the oak mottes, $19.8 \mathrm{~cm} \mathrm{~h}^{-1}$ for the bunchgrasses, and $13.8 \mathrm{~h}^{-1}$ for the sodgrasses. Sediment production pretreatment averaged $5 \mathrm{~kg} \mathrm{ha}^{-1}$ from oak mottes, $15 \mathrm{~kg}$ $\mathrm{ha}^{-1}$ from bunchgrasses, and $18.7 \mathrm{~kg} \mathrm{ha}^{-1}$ from sodgrass sites (Knight 1980, Knight et al. 1984).

Eight $0.5-\mathrm{m}^{2}$ randomly located runoff plots in each vegetation type and each pasture were sampled. Oak trees were cut by hand and carefully removed from the study plot area to facilitate equipment access. Plots were pre-wet by applying 100 liters of water via a mist-type nozzle over a $1.1-\mathrm{m}^{2}$ circular area. The plots were then covered with plastic and allowed to drain to field capacity. This procedure removed the variability that would have resulted from antecedent moisture conditions and allows direct comparison of all sites. Infiltration rates and sediment production were determined using a drip-type rainfall simulator (Blackburn et al. 1974). The simulated raindrops were $2.5 \mathrm{~mm}$ in diameter. Drops falling $2.1 \mathrm{~m}$ reach $5.25 \mathrm{~m} / \mathrm{sec}$ or $71 \%$ of the terminal velocity achieved by raindrops in an unlimited fall (Laws 1941). The simulated rainfall was applied at a rate of $203 \mathrm{~mm} \mathrm{~h}^{-1}$ for 50 minutes, which represents a storm return period of about $150 \mathrm{yr}$. This admittedly high rate was chosen to ensure that all plots would reach terminal infiltration rate. This criterion was desirable so that the rates could be compared between plant communities and grazing treatments. Runoff was continuously collected from each plot and was recorded by weight at 5 -minute intervals. Infiltration rates were determined by calculating the difference between the applied volume of simulated rainfall and the runoff. A l-liter subsample of the thoroughly mixed runoff was taken at the conclusion of the sample period. Each subsample was filtered through a tared \#1 Whatman filter. Sediment remaining on the filter was oven-dried, weighed, and converted to sediment production $\left(\mathrm{kg} \mathrm{ha}^{-1}\right)$ based on the area and total runoff from each plot and used as an index of sheet erosion.

The percentage and type of foliar cover in cach plot was determined by ocular estimate. Standing grass and standing forbs were clipped and litter was collected from each plot, separately dried at $60^{\circ} \mathrm{C}$ for $48 \mathrm{~h}$, weighed, and converted to $\mathrm{kg} \mathrm{ha}^{-1}$.

Soil cores were taken at the $0-30 \mathrm{~mm}$ and $50-80 \mathrm{~mm}$ depths adjacent to each plot prior to the initiation of the simulated rainfall. Soil bulk density was determined by the core method (Black 1965). Soil moisture content was determined by the gravimetric method (Gardner 1964).

A soil sample of the surface $50 \mathrm{~mm}$ was taken from each plot after the simulated rainfall test. Organic matter content was determined by the Walkley-Black method (Walkley and Black 1934), aggregate stability by the weight sieve method (Kemper and Koch 1965) and soil texture by the hydrometer method (Bouyoucos 1962).

Data normality was determined by tests for skewness and kurtosis. Values for sediment production were skewed and were therefore transformed using a $\log _{10}$ transformation. Differences between treatments were determined by analysis of variance. The error term in the analysis of variance consisted of the nested variation of the randomized sites within the treatments (Snedecor and Cochran 1971). Treatment means were separated by Duncan's new multiple range test (Duncan 1955). Significance levels were used to determine the degree of linear association of the measured variables, and forward stepwise multiple regression analysis (Draper and Smith 1981) was used to identify the set of variables that most influenced infiltration rate and sediment production.

\section{Results and Discussion}

Infiltration rates were greatest at the first $5 \mathrm{~min}$ reading for each vegetation type, and then declined in subsequent readings until a terminal infiltration rate was reduced. The shape of the mean infiltration rate curve for each of the vegetation types is shown in Figure 1. Mean infiltration rates for each of the 5 min sample

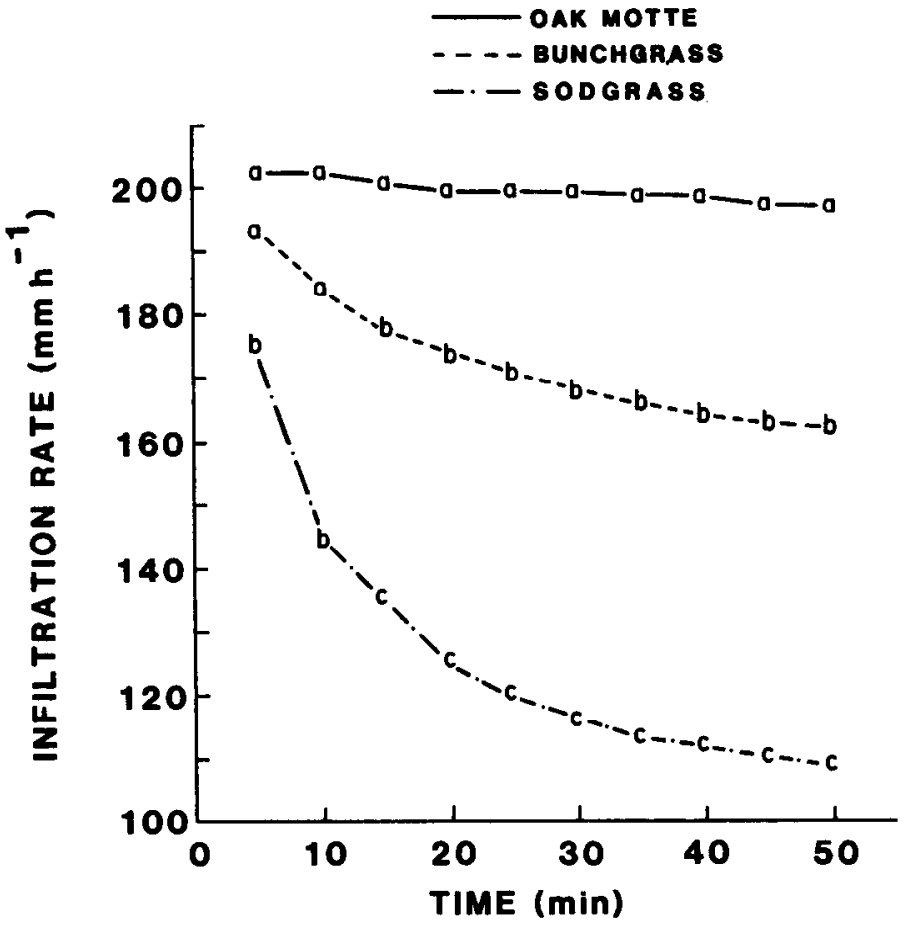

Fig. 1. Mean infiltration rate for the 3 vegetation types across the $50 \mathrm{~min}$ simulated rainfall application, Edwards Plateau, Texas. Means with the same letter for the same time period are not significantly different (P $\leq$ 05).

periods showed similar trends when correlated with other measured variables, but mean infiltration rates from measurements taken after 50 min always showed the greatest correlations. Therefore, in the following text, only mean infiltration rates after $50 \mathrm{~min}$ will be discussed.

Stepwise regression analysis was used to identify the set of measured variables that most effectively predicted infiltration rate. The following model $\left(R^{2}=.86\right)$ was developed:
Mean infiltration
(Total organic
rate after $50 \mathrm{~min}=9.32+0.16$
cover) -8.57
Bulk density 0-30 mm).

Total organic cover was the variable most strongly correlated with infiltration rate $\left(R^{2}=.80\right)$ (Fig. 2). The total organic cover under oak mottes was consistently higher than in the grass interspace, and bunchgrass sites were significantly greater than the sodgrass sites. There was no difference between grazing treatment pastures in total organic cover in oak mottes due to the great accumulation of oak leaf litter. The bunchgrass and sodgrass vegetation types had less total organic cover in the HCG and SDG systems than in the MCG and LEX pastures.

The second most important variable of the infiltration rate multiple regression model was the bulk density of the soil surface $\left(R^{2}=0.61\right)$. Bulk density did not differ among grazing treatments. The surface bulk densities of the bunchgrass vegetation type $(0.93$ $\left.\mathrm{Mg} \mathrm{m}^{-3}\right)$ and sodgrass vegetation type $\left(0.92 \mathrm{MG} \mathrm{m}^{-3}\right)$ were not significantly different, but both were significantly greater than the oak motte surface bulk density $\left(0.69 \mathrm{Mg} \mathrm{m}^{-3}\right)$. Bulk density was negatively related to aggregate stability $\left(R^{2}=.59\right)$, soil organic matter content $\left(R^{2}=0.61\right)$ and clay soil texture $\left(R^{2}=.40\right)$ indicating that the bulk density measurement integrates several aspects of soil structure. Aggregate stability and soil organic matter did not differ among grazing treatments but did differ among vegetation types. Aggregate stability was significantly greater in the oak mottes $(86.0 \%)$ than on either bunchgrass $(77.4 \%)$ or sodgrass $(73.2 \%)$ sites. Likewise, soil organic matter was significantly greater in the 


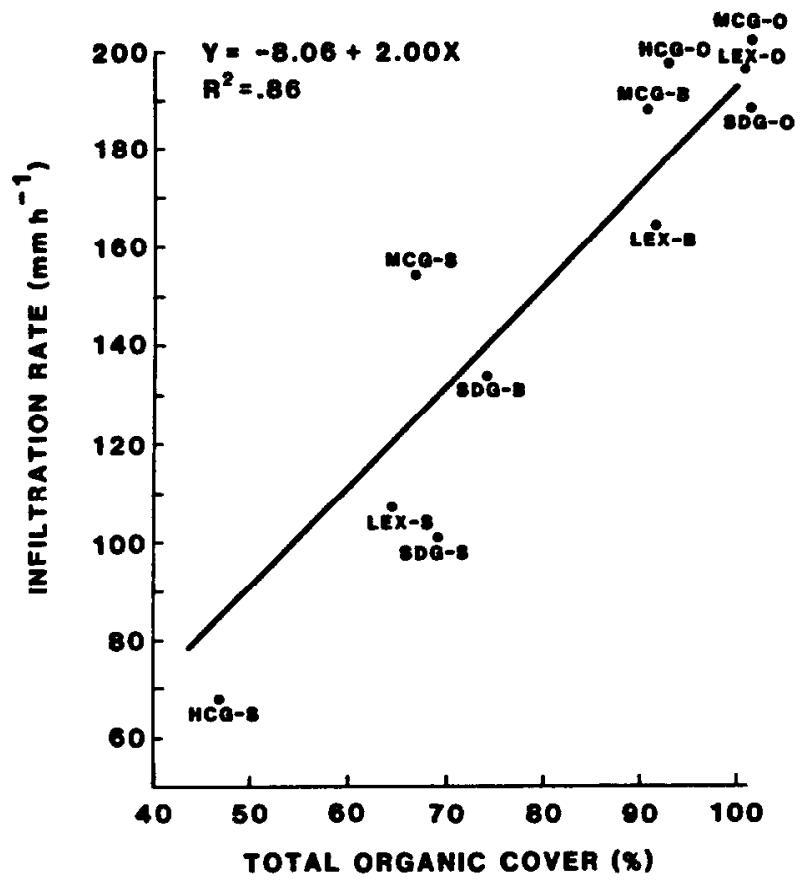

Fig. 2. Relationship of infiltration rate with total organic cover (\%) for heavy continuous ( $H C G$ ), short-duration (SDG), moderate continuous (MCG) and livestock exclosure (LEX) pastures, Edwards Plateau, Texas. ( $O=$ oak motte, $B=$ bunchgrass, $S=$ sodgrass).

oak mottes $(11.2 \%)$ than in either the bunchgrass $(5.5 \%)$ or sodgrass $(5.6 \%)$ sites.

Both variables in the infiltration rate equation are related to the integrity of the surface soil pore structure. The linear relationship of total organic matter with infiltration rate shows that the type of organic cover is not as important as the amount. The primary role of cover from an infiltration standpoint is that it decreases the kinetic energy of the raindrops before they strike the soil. This protects the pore integrity of the surface structure by dissipating the raindrop impact velocity, thus reducing the disaggregating potential of the rain. Thus, pores are less likely to be clogged by disaggregated soil particles. Bulk density is also a measurement of soil structure, giving an indication of the volume of passages available into which water may pass.

The following model $\left(R^{2}=.79\right)$ was developed to determine the set of variables that would be most effective for predicting sediment production:

Mean sediment production Total aboveafter $50 \mathrm{~min}=5.15+0.03$ (ground biomass) -0.01 (Bunchgrass Cover)

Total aboveground biomass was the variable most strongly correlated with sediment production $\left(R^{2}=.65\right)$ (Fig. 3). Total aboveground biomass and bunchgrass cover were not strongly correlated $\left(R^{2}=.31\right)$, because the total aboveground biomass estimate was strongly influenced by leaf litter in the oak mottes.

Bunchgrass cover was the second most important variable of the sediment production model $\left(R^{2}=-.63\right)$. There was a significant difference in bunchgrass cover (primarily composed of Texas wintergrass) under the oak mottes, with the LEX (34\%) and MCG (20\%) pastures having significantly greater bunchgrass cover than either the SDG $(7 \%)$ or HCG (4\%) pastures. This same pattern was found in the bunchgrass interspace with the MCG $(68 \%)$ and LEX (58\%) pastures having significantly greater cover than the SDG (32\%) pasture. There was no bunchgrass interspace in the HCG pasture.

Total aboveground biomass protects the soil surface from the

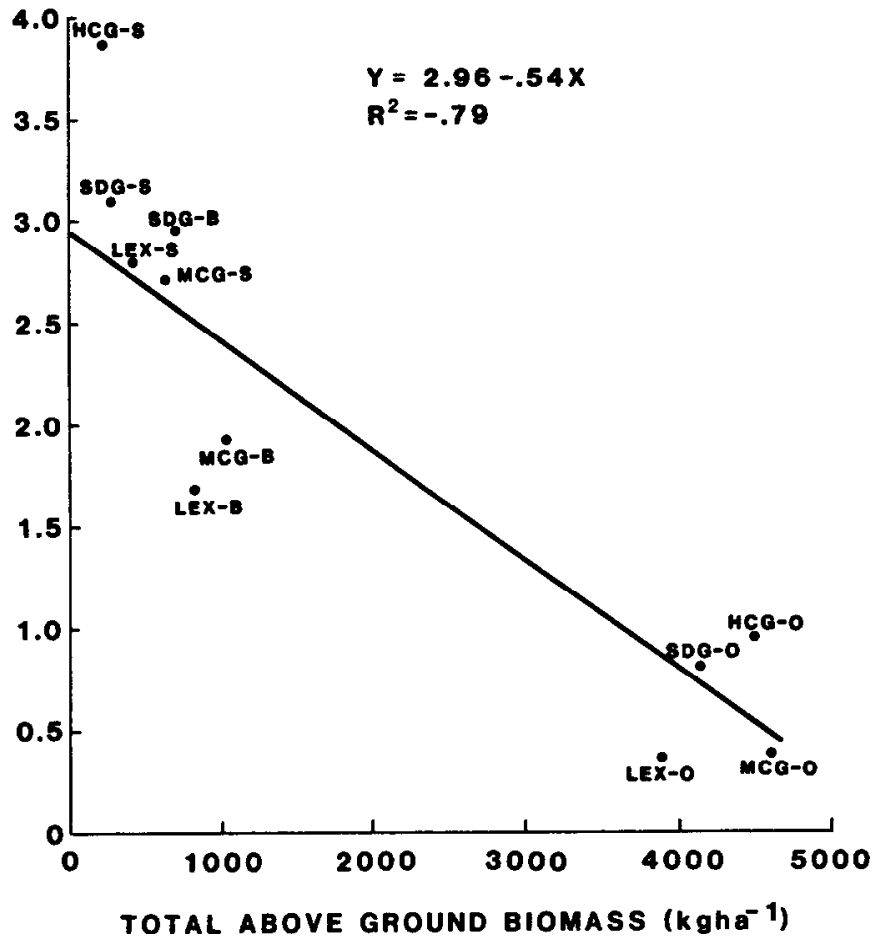

Fig. 3. Relationship of the $\log _{10}$ sediment production with total aboveground biomass ( $\mathrm{kg} \mathrm{ha}^{-1}$ ), for heavy continuous (HCG), short-duration (SDG), moderate continuous (MCG), and livestock exclosure (LEX) pastures, Edwards Plateau, Texas. $(0=$ oak motte, $B=$ bunchgrass, $S=$ sodgrass).

disaggregating affects of direct raindrop impact. Both total aboveground biomass and bunchgrass cover also serve as barriers to sediment transport by causing overland flow to move in a slower, more torturous path. Thus, the obstruction provided by the bunch growth form and litter is an important determinant of sediment loss. The negative relationship of bunchgrass cover with sediment loss contrasts with the sodgrass growth form which does not provide a large obstruction barrier and thus has a poor, negative relationship to sediment production $\left(R^{2}=-.34\right)$.

The differences in infiltration rate and sediment production between treatment pastures are shown in Figures 4 and 5 . These

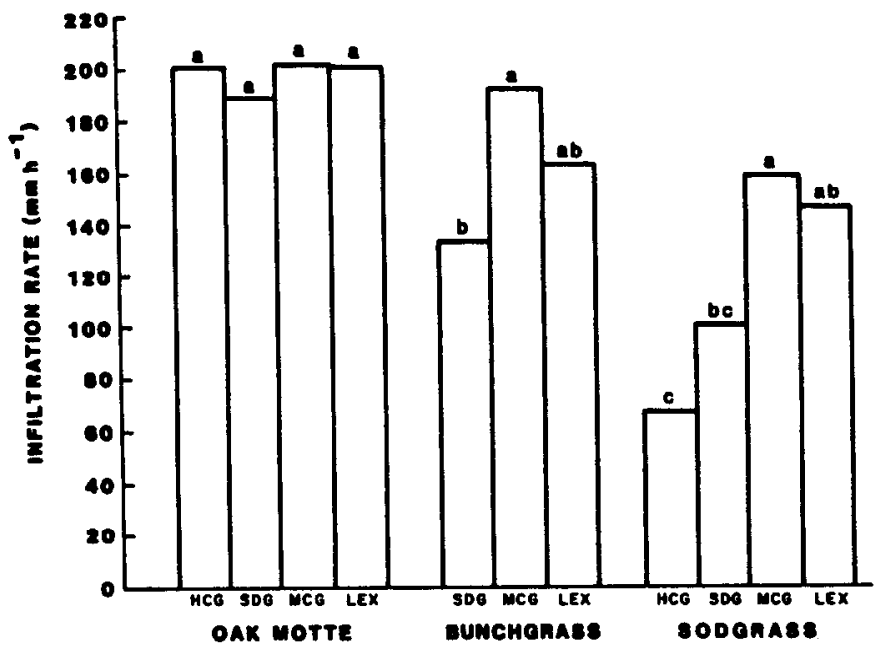

Fig. 4. Mean infiltration rate $\left(m m h^{-1}\right)$ for heavy continuous (HCG), short-duration (SDG), moderate continuous (MCG), and livestock exclosure (LEX) treatments and vegetation types, Edwards Plateau, Texas. Means with the same letter in each vegetation type are not significantly different $(\mathrm{P} \leq 05)$. 


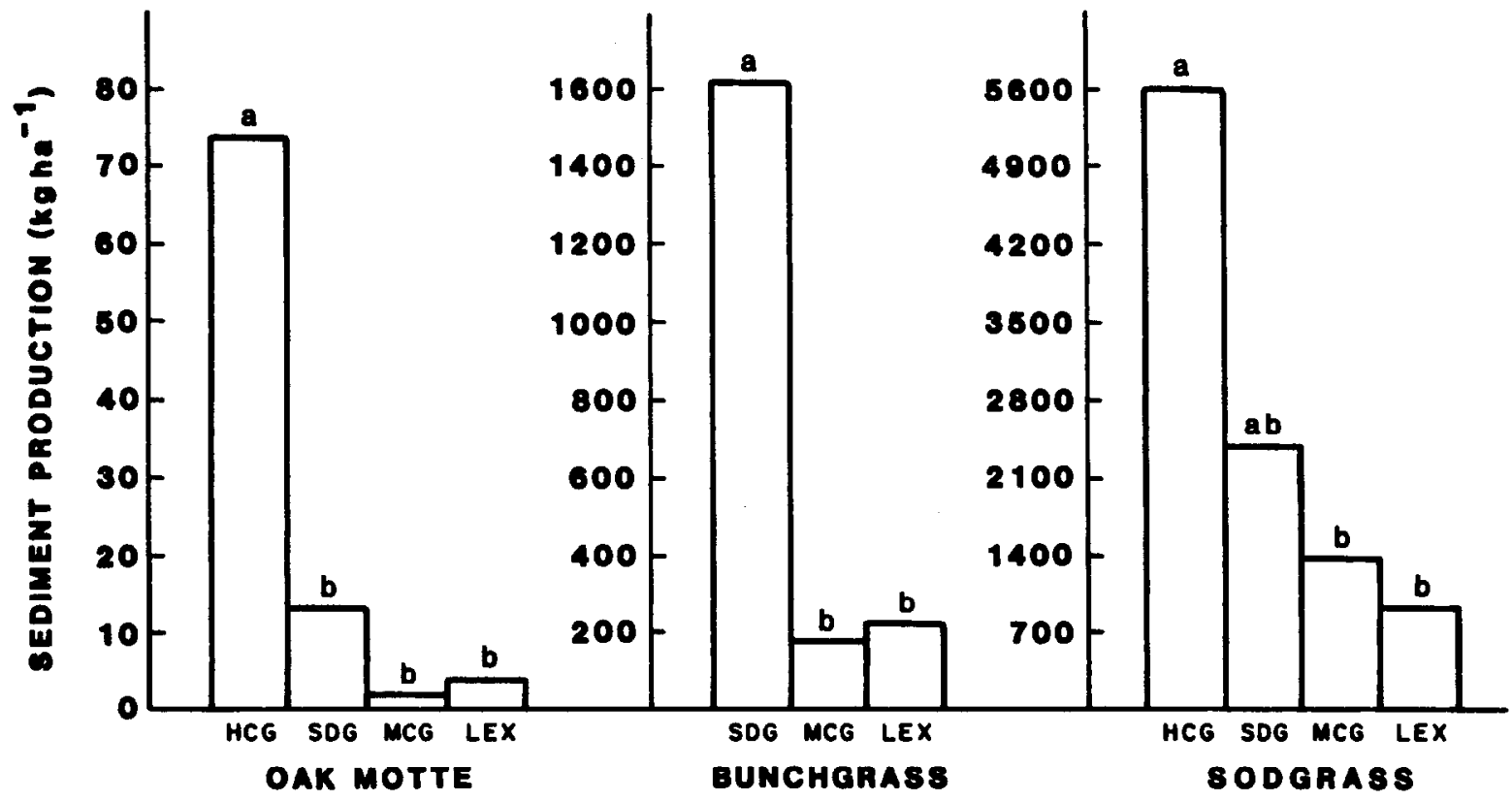

Fig. 5. Mean sediment production $\left(m m h^{-1}\right.$ ) for heavy continuous (HCG), short-duration (SDG), moderate continuous (MCG), and livestock exclosure (LEX) treatments and vegetation types, Edwards Plateau, Texas (Note that sediment production scale changes). Means with the same letter in each vegetation type are not significantly different ( $P \leq 05)$.

patterns can be explained by the relationship of factors that characterize each pasture as expressed in the 2 regression models described above. An exception to the sediment regression model exists for the significantly greater sediment production from the HCG oak mottes compared to the oak motte sediment production of other treatments. The sediment yield from the HCG oak mottes was 12 times greater than sediment yield from the oak mottes in the other pastures even though oak motte infiltration rates on all 4 treatments were similar. This may be a result of the heavy sheet erosion that has been occurring in the grass interspace of the HCG pasture since that system was established in 1978. Based on runoff data from $3(1.8 \mathrm{~m}$ by $22.1 \mathrm{~m})$ natural runoff plots in each of the HCG, MCG and SDG pastures, the natural runoff from the HCG pasture averaged an annual sediment loss of $700 \mathrm{~kg} \mathrm{ha}^{-1}$ compared to $250 \mathrm{~kg} \mathrm{ha}^{-1}$ for the MCG and $563 \mathrm{~kg} \mathrm{ha}^{-1}$ for the SDG pastures. Sediment suspended in grass-interspace-overland flow would be dropped when the runoff encounters the oak motte soils whose structure can accommodate a water infiltration rate in excess of most natural runoff events. Such overland flow events are essentially limited to the grass interspace since the much greater infiltration rate of the oak mottes would rarely be exceeded by natural precipitation events. Consequently, soil and nutrients eroded from the grass interspace are deposited in the oak mottes. This increased deposition of sediment in the HCG oak mottes over the past 6 years probably accounts for the greater sediment production. This pattern of soil erosion in the grass interspace and sediment deposition in oak mottes has led to oak mottes being visibly mounded in pastures on the Edwards Plateau that have been heavily grazed for many decades.

Oak mottes had a significantly higher sand content (27.2\%) than the bunchgrass $(19.5 \%)$ or sodgrass $(18.1 \%)$ sites. In a random sample of 100 soil cores on the treatment pastures it was established that sand content was strongly correlated negatively with soil depth $\left(R^{2}=-0.85\right)$. An explanation for oak mottes being generally associated with the shallower, sandy textured soils may be related to competition during seedling establishment. On the deeper clay sites grasses would have access to the volume of water stored above the fractured caliche layer and thus could effectively compete against oak seedling establishment. However, on shallow sites, competition during seedling establishment would be lower. If the oak seedling roots could penetrate the fractured caliche and tap a deeper water source it would then be relatively free from grass competition for water. Once the oak is established, the affects of the greater litter deposition would increase the organic matter content of the soil and would aid aggregate stability and decrease bulk density. The enhancement of these soil structure factors could also be aided by microclimate factors which could aid microorganism activity. Such changes that aid soil structure development would aid the ability of the oak motte to retain water and nutrients eroding from the grass interspace. The large amounts of leaf litter and the cool-season bunchgrasses which are associated with the oak mottes provide effective barriers that slow overland flow and cause sediment deposition.

\section{Literature Cited}

Black, C.A. (ed.). 1965. Methods of soil analysis. Amer. Soc. Agron. Series No. 9, Madison, Wis.

Blackburn, W.H. 1975. Factors influencing infiltration and sediment production of semiarid rangelands in Nevada. Water Resour. Res. 11:929-937.

Blackburn, W.H., R.O. Meeuwig, and C.M. Skau. 1974. A mobile infiltrometer for use on rangeland. J. Range Manage. 27:322-323.

Bouyoucos, G.J. 1962. Hydrometer method improved for making particle size analysis of soil. Agron. J. 54:464-465.

Box, T.W. 1961. Relationships between plants and soils of 4 range plant communities with south Texas. Ecology 42:794-810.

Draper, N.R., and H. Smith. 1981. Applied regression analysis. John Wiley and Sons, Inc., New York, NY.

Duncan, D.B. 1955. Multiple range and multiple F test. Biom. 11:1-42.

Dunford, E.G., and S. Weitzman. 1955. Managing forests to control soil erosion. p. 235-247. In: Water, USDA Yearbook, 1955.

Dyksterhuis, E.J. 1949. Condition and management of rangeland based on quantitative ecology. J. Range Manage. 2:104-115.

Ellison, L. 1960. Influence of grazing on plant succession of rangelands. Bot. Rev. 26:1-78.

Gardner, W.H. 1965. Water content, p. 82-125. In: C.A. Black (ed.) Methods of soil analysis (Part 1). Amer. Soc. Agron. Agron. Ser. No. 9, Madison, Wis.

Kemper, W.D., and E.J. Koch. 1965. Aggregate stability of soils from the western portions of the U.S. and Canada. USDA Tech. Bull. 1355.

Knight, R.W. 1980. Hydrologic response of selected grazing systems on the Edwards Plateau. Ph.D. Diss., Texas A\&M Univ., College Station.

Knight, R.W., W.H. Blackburn, and L.B. Merrill. 1984. Characteristics of oak mottes, Edwards Plateau, Texas. J. Range Manage. 37:534-537. 
Laws, J.O. 1941. Measurements of the fall-velocity of water-drops and raindrops. Trans. Amer. Geophys. Union 22:709-721.

Reed, M.J., and R.A. Peterson. 1961. Vegetation, soil, and cattle responses to grazing on Northern Great Plains range. USDA Tech. Bull. 1252.

Rhoades, E.D., L.F. Locke, H.M. Taylor, and E.H. McIlvain. 1964. Water intake on a sandy range as affected by 20 years of differential cattle stocking rates. J. Range Manage. 17:185-190.

Rich, R.L., and H.G. Reynolds. 1963. Grazing in relation to erosion on some chaparral watersheds of central Arizona. J. Kange Manage. 16:322-326.

Sharp, A.L., L.J. Bond, J.W. Neuberger, A.R. Kuhlman, and J.K. Lewis. 1964. Runoff as affected by intensity of grazing on rangeland. J. Soil Water Conserv. 19:103-106.
Smith, H.L., and L.R. Leopold. 1941. Infiltration studies in the PecosRiver Watershed, New Mexico and Texas. Soil Sci. 53:195-204.

Snedecor, G.W., and W.G. Cochran. 1971. Statistical methods. Iowa State University Press, Ames.

Walkley, A., and A.I. Black. 1934. An examination of the Deqtjareff method for determining soil organic matter and a proposed modification of the chromic acid titration method. Soil Sci. 37:29-38.

Wood, M.K., and W.H. Blackburn. 1981. Grazing systems: Their influence on infiltration rates in the rolling plains of Texas. J. Range Manage. 34:331-335.

Woodward, L. 1943. Infiltration capacities on some plant-soil complexes on Utah range watershed lands. Trans. of Amer. Geophys. Union. $24: 468-475$. 